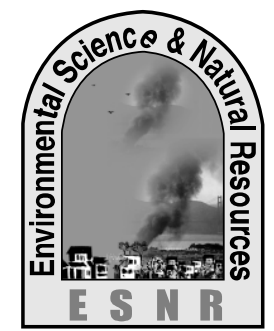

\title{
Physicochemical Properties and Metallic Constituent Load in the Water Samples of the Buriganga of Bangladesh
}

\author{
K. M. Mohiuddin", M. M. Alam, I. Ahmed, H. M. Zakir and A. K. Chowdhury
}

Department of Agricultural Chemistry, Bangladesh Agricultural University, Mymensingh2202, Bangladesh

*Corresponding author: mohiagchem@gmail.com

\begin{abstract}
The study was conducted to assess the level of $\mathrm{Cu}, \mathrm{Zn}, \mathrm{Pb}, \mathrm{Cr}, \mathrm{Fe}, \mathrm{Mn}, \mathrm{Cd}$ and $\mathrm{Ni}$ contamination in the water samples of the Buriganga river. Total 14 water samples were collected from different areas of upstream of the Buriganga river to determine the physicochemical properties, concentration of different metallic constituents and assess the heavy metal pollution load. Atomic Absorption Spectrometer was used for analyzing the heavy metals of the samples. The mean concentration of $\mathrm{Ca}, \mathrm{Mg}, \mathrm{Na}, \mathrm{K}$ in water samples were 0.779 , $0.889,140.39,26.9 \mu \mathrm{g} \mathrm{mL}^{-1}$, respectively. The mean concentration of $\mathrm{Cr}, \mathrm{Pb}, \mathrm{Fe}, \mathrm{Cu}, \mathrm{Zn}$ and $\mathrm{Mn}$ in the water samples were $0.17,0.05$, $0.67,0.22,0.55$ and $0.17 \mu \mathrm{g} \mathrm{mL}^{-1}$, respectively. The amount of $\mathrm{Cd}$ in all samples and $\mathrm{Pb}$ in 10 samples was below detectable limit of the instrument $\left(0.01 \mu \mathrm{g} \mathrm{mL}^{-1}\right)$. Water $\mathrm{pH}$ ranged from 4.09 to 7.41 and EC was 346 to $7720 \mu \mathrm{S} \mathrm{cm}^{-1}$. Magnitude of heavy metal pollution in the Buriganga river system implies that the condition is very alarming and may severely affect the aquatic ecology of the river. To minimize the severe impact on city dwellers and aquatic ecology of the Buriganga river, sustainable steps and continuous monitoring on pollution prevention and cleanup operation is suggested.
\end{abstract}

Key words: Buriganga river, Heavy metal, Pollution load, Water quality

\section{Introduction}

Heavy metals exhibit extreme toxicity even at trace levels. Rivers are a dominant pathway for metals transport (Miller et al., 2003) and heavy metals become significant pollutants of many riverine systems (Dassenakis et al., 1998). In Bangladesh, river water are largely used for agricultural purposes. But presence of hazardous substances such as $\mathrm{As}, \mathrm{Cr}, \mathrm{Cd}, \mathrm{Pb}, \mathrm{Cu}, \mathrm{Ni}$, $\mathrm{Fe}, \mathrm{Zn}, \mathrm{Mn}, \mathrm{Hg}$ and toxic microbes, consequently river water becomes polluted. The chemical characteristics of water determine its quality as well as its usefulness for irrigation, industrial and domestic usage. In Bangladesh, the research on the aspect of wastewater pollution is yet at an initial stage and literature in this connection is very scanty. In the distant past, a course of the Ganges river used to reach the Bay of Bengal through the Dhaleshwari river. This course gradually shifted and ultimately lost its link with the main channel of the Ganges and was renamed as the Buriganga. The river Buriganga is the main river flowing beside Dhaka, the capital of Bangladesh, which is a megacity of 12 million people. City dwellers largely depend on the Buriganga's water for cleaning utensils and other commodities, fishing and carrying merchandise. Unfortunately it is now considered as one of the dirtiest rivers of the world. The foul odour of the polluted blackish water of the Buriganga river can be sensed even from half a kilometer distance. Intensive human intervention, unplanned urbanization and population pressure have created the present unwanted situation of the river. As a result of insensible human actions on the one hand, and failure by the authority to enforce rules and regulations to save the river on the other, the Buriganga is dying biologically (Alam, 2008). Nowadays, no fish and other aquatic animals are found in the river during the dry season. According to the experts, one among the major reasons of pollution in the Buriganga is the Hazaribagh tannery. Although the tannery is 46 years old but no treatment plant has been introduced yet to neutralize the noxious materials it produces. That's why it continuously pollutes the water of the Buriganga. Most of the previous studies have been focused mainly on the Buriganga river water chemistry (Ali et al., 2008; Moniruzzaman et al., 2009; Alam et al, 2003; Ahmad et al., 2010). Mohiuddin et al., (2011) collected water samples from the Buriganga river to observe the seasonal and spatial distribution of heavy metals and reported extreme heavy metal pollution load in the water samples. However, in the mean time Govt. of Bangladesh has taken various steps to clean up Buriganga river. In 2010, Bangladesh Inland Water Transport Authority (BIWTA) began extracting hundreds of thousands of tonnes of garbage from the Buriganga river that being slowly choked by waste, mostly non-biodegradable polythene bags. In June 2011, The High Court of Bangladesh directed the chairman of Dhaka Water Supply and Sewerage Authority (WASA) to take steps to seal off the waste outlets and asked the Dhaka City Corporation to immediately start cleaning the riverbanks to stop dumping any more waste into or by the river. In 2012, BIWTA completed a mega project namely 'Construction of port facilities in order to prevent unauthorized encroachment of Buriganga river and its foreshore land'. To remove wastes from the Buriganga river, 'Deposited Polythene and Other Waste Removal from Buriganga and Turag Rivers' project was implemented by BIWTA in 2013. Considering the above facts, the present research was planned to carry out to follow up assessment of the heavy metal pollution load in the water samples of the Buriganga river, Bangladesh.

\section{Materials and Methods}

\section{Sampling}

Water samples were collected from 14 sites of the Buriganga river in January 2014 (Table 1 and Fig. 1). About $200 \mathrm{~mL}$ water samples were collected from each location in two plastic containers, following the method as described by APHA (2005). These containers were cleaned with dilute $\mathrm{HCl}(1: 1)$ and then washed with 
distilled water. Water samples were immediately filtered with ADVANTEC ${ }^{\circledR} 0.2 \mu \mathrm{m}$ size sterile syringe filter. For the analysis of heavy metals $100 \mathrm{~mL}$ water sample was collected in separate clean bottle and acidified with $0.5 \mathrm{~mL}$ conc. nitric acid to maintain $\mathrm{pH}$ below 2, which will prevent the loss of metals by absorption and/ or ion exchange with the walls of glass containers.

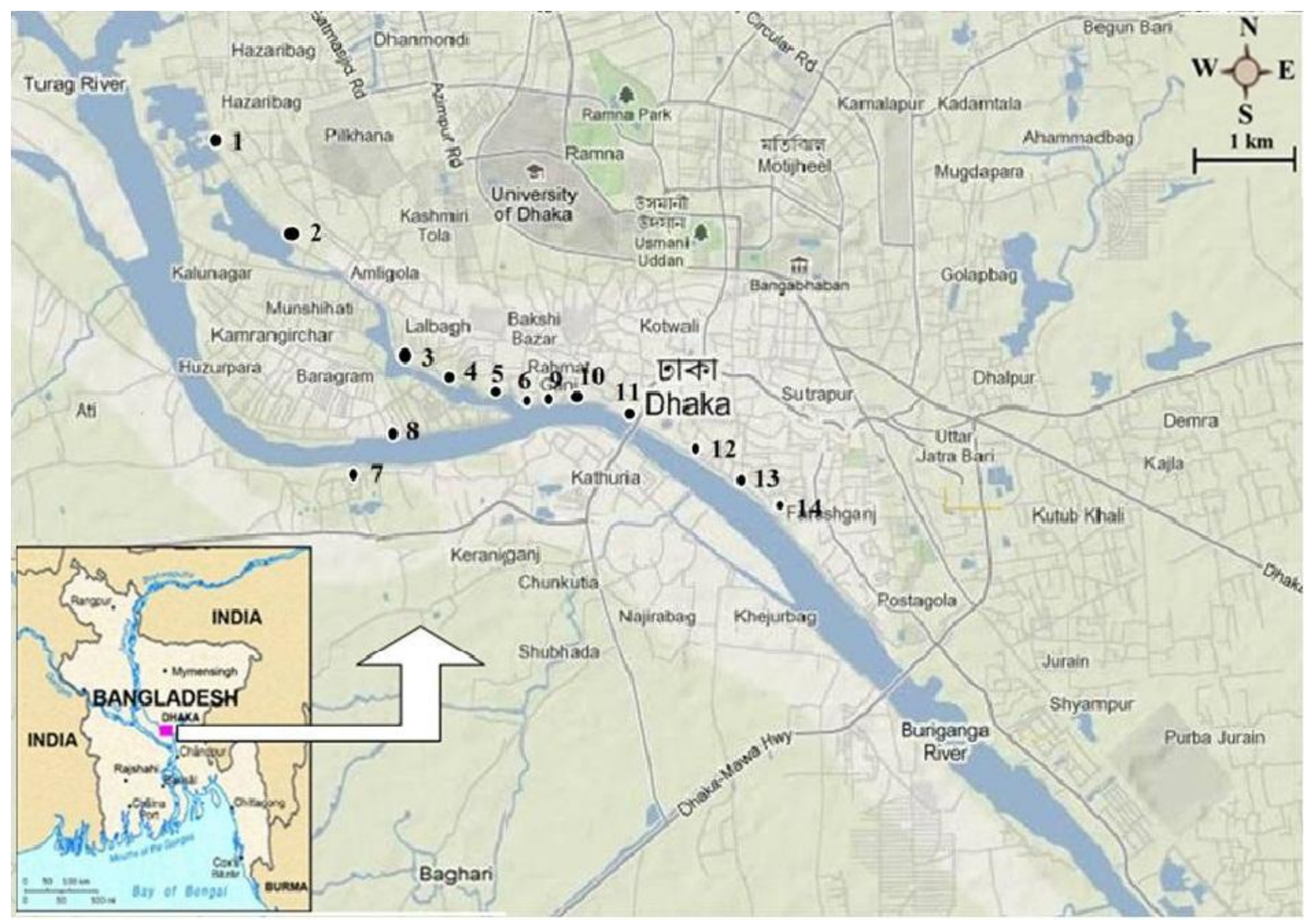

Fig. 1. Location of different sampling sites of Buriganga River, Dhaka, Bangladesh

Table 1. Name of the locations of different sampling sites of the river Buriganga, Dhaka, Bangladesh

\begin{tabular}{clcl}
\hline Sample No. & Location & Sample No. & Location \\
\hline 1 & Hazaribag - ZH Sikder MC & 8 & Kamrangirchor Tara Masjid \\
2 & Nobabgonj Bara Masjid & 9 & Swarighat \\
3 & Shohid Nagar Beribadh & 10 & Razar ghat \\
4 & Kellarmor Truck Stand & 11 & Badamtoli Bridge \\
5 & Islambag Alir ghat & 12 & Nowab Barir Ghat \\
6 & Raghunathpur & 13 & Sadar Ghat \\
7 & Borishur Lonch Terminal & 14 & Mererbag \\
\hline
\end{tabular}

\section{Analysis of water samples}

The $\mathrm{pH}$ value of water samples was measured by taking $90 \mathrm{~mL}$ of water in $100 \mathrm{~mL}$ beaker and immersing the electrode of $\mathrm{pH}$ meter (SensION+EC5, HACH, USA) into samples as mentioned by Singh et al. (1999). EC of the samples was measured with the help of EC meter $\left(\right.$ SensION $\left.{ }^{\mathrm{TM}}+\mathrm{EC} 5, \mathrm{HACH}, \mathrm{USA}\right)$ following the method as outlined by Singh et al. (1999). Calcium and magnesium were determined from water samples by titrimetric method using $\mathrm{Na}_{2}$ EDTA as a chelating agent at pH 12 (Page et al., 1982). Potassium and $\mathrm{Na}$ contents determined by flame emission spectrophotometer (Model: JENWAY PFP7, UK). Heavy metals such as chromium $(\mathrm{Cr})$, lead $(\mathrm{Pb})$, cadmium $(\mathrm{Cd})$, iron $(\mathrm{Fe})$, zinc $(\mathrm{Zn})$, copper $(\mathrm{Cu})$, nickel $(\mathrm{Ni})$ and Manganese $(\mathrm{Mn})$ in acidified water samples were analyzed by
Atomic Absorption Spectrophotometer (AA-7000; SHIMADZU, Japan).

\section{Results and Discussion}

\section{Physicochemical properties of water}

The $\mathrm{pH}$ value of all water samples varied from 4.09 to 7.41 (Table 2). Out of 14 samples, 10 samples varied from 4.09 to 5.74 and rest of 04 samples ranged from 6.73 to 7.41 . These might be due to the presence of higher amount of industrial waste in water. According to Ayers and Westcot (1985), the acceptable range of $\mathrm{pH}$ for irrigation water is from 6.0 to 8.4. So, the measured $\mathrm{pH}$ of 10 samples under the investigation area was problematic for long-term irrigation. On the other hand, according to US EPA (2009), the guideline value of $\mathrm{pH}$ for drinking water is from 6.5 to 8.5 . Out of 14 
samples, 04 samples were within the permissible value. These waters were suitable for drinking but 10 samples were below the permissible limit and found unsuitable for drinking. The EC is the total concentration of soluble salts in the sample. In this study, EC of the water samples ranged from 346 to $7720 \mu \mathrm{S} \mathrm{cm}^{-1}$ with an average value of $2798 \mu \mathrm{S} \mathrm{cm}^{-1}$ (Table 3 ). The highest EC $\left(7720 \mu \mathrm{S} \mathrm{cm}^{-1}\right)$ was recorded in the sample no. 10 and the lowest $\left(346 \mu \mathrm{S} \mathrm{cm} \mathrm{cm}^{-1}\right)$ was obtained in the sample no. 08. Higher EC value reflected the higher amount of salt concentration which affected irrigation water quality related to salinity hazard (Agarwal et al., 1982). The acceptable limit of EC for irrigation water is
$750 \mu \mathrm{S} \mathrm{cm}-1$ and fishing water is 500 to $1000 \mu \mathrm{S} \mathrm{cm}^{-1}$ (ADB, 1994). On the basis of measured EC, out of 14 samples 09 water samples exceeded the acceptable limit of irrigation water quality. According to Richards (1968), 05 samples under test were rated in the category $\mathrm{C} 2\left(\mathrm{EC}=250-750 \mu \mathrm{S} \mathrm{cm}^{-1}\right), 01$ sample in the category $\mathrm{C} 3\left(\mathrm{EC}=751-2250 \mu \mathrm{S} \mathrm{cm}^{-1}\right)$ and the rest 08 samples in the category $\mathrm{C} 4\left(\mathrm{EC}=>2251 \mu \mathrm{S} \mathrm{cm} \mathrm{cm}^{-1}\right)$ indicating medium to very high salinity. Medium salinity class water might be applied with moderate leaching. High salinity class waters were treated as unsuitable for irrigation purpose (Agarwal et al., 1982).

Table 2. Physicochemical properties ( $\mathrm{pH}$ and EC) of water samples collected from different sites of Buriganga River, Bangladesh

\begin{tabular}{|c|c|c|}
\hline Sample No. & $\mathbf{p H}$ & $\mathbf{E C}\left(\boldsymbol{\mu} \mathbf{~ c m}^{-\mathbf{1}}\right)$ \\
\hline 1 & 5.74 & 947 \\
\hline 2 & 4.09 & 3490 \\
\hline 3 & 4.89 & 3960 \\
\hline 4 & 5.08 & 2850 \\
\hline 5 & 5.05 & 2860 \\
\hline 6 & 6.73 & 524 \\
\hline 7 & 7.27 & 492 \\
\hline 8 & 5.02 & 346 \\
\hline 9 & 4.82 & 5790 \\
\hline 10 & 4.66 & 7720 \\
\hline 11 & 4.78 & 5630 \\
\hline 12 & 4.95 & 3500 \\
\hline 13 & 7.41 & 594 \\
\hline 14 & 6.87 & 474 \\
\hline Range & $\mathbf{4 . 0 9 - 7 . 4 1}$ & $\mathbf{3 4 6 - 7 7 2 0}$ \\
\hline Mean & $\mathbf{5 . 5}$ & $\mathbf{2 7 9 8}$ \\
\hline DWGV & $\mathbf{6 . 5 - 8 . 5 ^ { \mathbf { a } }}$ & - \\
\hline IWGV & $\mathbf{6 . 0 ~ 8 . 4 ^ { \mathbf { b } }}$ & $\mathbf{7 5 0}^{\mathbf{c}}$ \\
\hline
\end{tabular}

DWGV: Drinking Water Guideline Value;

IWGV: Irrigation Water Guideline Value

a - US EPA (2009); ${ }^{\text {- }}$ - Ayers and Westcot (1985); ${ }^{\mathrm{c}}$ - ADB (1994)

\section{Heavy metals in water samples}

The concentration of $\mathrm{Cr}$ in water samples ranged from 0.130 to $0.209 \mu \mathrm{g} \mathrm{mL}^{-1}$ with a mean value of $0.172 \mu \mathrm{g}$ $\mathrm{mL}^{-1}$ (Table 3). The US EPA regulates total $\mathrm{Cr}$ in drinking water and has set a Maximum Contaminant Level (MCL) of $0.1 \mu \mathrm{g} \mathrm{mL} \mathrm{m}^{-1}$. The World Health Organization (WHO) guideline is $0.05 \mu \mathrm{g} \mathrm{mL}^{-1}$ for total $\mathrm{Cr}$. In all the collected water samples concentration of $\mathrm{Cr}$ was recorded above the Maximum Contaminant Level (MCL) of US EPA. Out of 14 samples, 06 samples were below the mean value. The concentration of $\mathrm{Pb}$ in water samples collected from different sites of Buriganga river varied from Below detectable limit of the instrument AA7000 to $0.097 \mu \mathrm{g} \mathrm{mL}^{-1}$ with a mean value of $0.054 \mu \mathrm{g} \mathrm{mL}^{-1}$ (Table 3). The standard of $\mathrm{Pb}$ for domestic water supplies is $<0.05 \mu \mathrm{g} \mathrm{mL} \mathrm{m}^{-1}$ as reported by USPH and $0.01 \mu \mathrm{g} \mathrm{mL}^{-1}$ as stated by ISI (De, 2002). The standard of $\mathrm{Pb}$ for drinking water is $0.05 \mu \mathrm{g} \mathrm{mL}^{-1}$; fishing water is $0.05 \mu \mathrm{g} \mathrm{mL}^{-1}$; industrial water is $0.01 \mu \mathrm{g} \mathrm{mL}^{-1}$; irrigation water is $0.05 \mathrm{mg} \mathrm{L}^{-1}$ and livestock water is $0.05 \mu \mathrm{g} \mathrm{mL}^{-1}$ (ADB, 1994). According to international standards for inland surface water, tolerance limit of $\mathrm{Pb}$ for public supply and bathing is $0.1 \mu \mathrm{g} \mathrm{mL}^{-1}$ (Ayers and Westcot, 1985). According to Bangladesh Standards, $\mathrm{Pb}$ content for irrigation water is $0.01 \mu \mathrm{g} \mathrm{mL}^{-1}$ (DoE, 2005).

Considering these limits, $\mathrm{Pb}$ concentrations in 10 water samples collected from the study area were found suitable and other samples were unsuitable for drinking, fishing, industrial and irrigation purposes in respect of $\mathrm{Pb}$ content. Similar observations were reported by Rahman et al. (2012) for Turag river and Bakali et al. (2014) for Tongi area water quality. The concentration of $\mathrm{Pb}$ in water samples collected from different sites of Buriganga river contained below detectable limit (BDL) of the instrument AA7000 (Table 3), which indicates that all of these waters can safely be used for different purposes in respect of $\mathrm{Cd}$. All the water samples collected from different sites of the Buriganga river contained comparatively different amount of iron $(\mathrm{Fe})$ and the amount varied from 0.301 to $1.549 \mu \mathrm{g} \mathrm{mL}^{-1}$ with a mean value of $0.671 \mu \mathrm{g} \mathrm{mL}^{-1}$ (Table 3 ). The recorded $\mathrm{Fe}$ concentrations of all the samples were far 
below the acceptable limit $\left(5.00 \mu \mathrm{g} \mathrm{mL}^{-1}\right)$ for irrigation as reported by Ayers and Westcot (1985), and could safely be used for long term irrigation without any detrimental effect on soil. According to US EPA
(2009), the guideline value of Fe for drinking water is $0.30 \mu \mathrm{g} \mathrm{mL}^{-1}$ (Table 4). From the results mentioned above it can be inferred that all water samples were unsuitable for drinking in respect to $\mathrm{Fe}$ content.

Table 3. Concentration of heavy metal in water samples collected from different sites of Buriganga River, Bangladesh

\begin{tabular}{|c|c|c|c|c|c|c|c|}
\hline \multirow{2}{*}{ Sample No. } & \multicolumn{7}{|c|}{ Heavy metal concentration $\left(\mu \mathrm{g} \mathrm{mL} \mathbf{L}^{-1}\right)$} \\
\hline & $\mathrm{Cr}$ & $\mathbf{P b}$ & Cd & $\mathbf{F e}$ & $\mathbf{C u}$ & Zn & Mn \\
\hline 1 & 0.130 & BDL & BDL & 1.549 & 0.197 & 0.239 & 0.276 \\
\hline 2 & 0.136 & BDL & BDL & 0.940 & 0.214 & 0.601 & 0.174 \\
\hline 3 & 0.147 & $\mathrm{BDL}$ & $\mathrm{BDL}$ & 1.426 & 0.210 & 0.818 & 0.235 \\
\hline 4 & 0.140 & $\mathrm{BDL}$ & BDL & 0.519 & 0.213 & 0.569 & 0.235 \\
\hline 5 & 0.176 & BDL & BDL & 0.888 & 0.209 & 0.594 & 0.170 \\
\hline 6 & 0.174 & BDL & BDL & 0.651 & 0.219 & 0.415 & 0.185 \\
\hline 7 & 0.209 & BDL & $\mathrm{BDL}$ & 0.920 & 0.208 & 0.547 & 0.105 \\
\hline 8 & 0.203 & BDL & $\mathrm{BDL}$ & 0.440 & 0.223 & 0.780 & 0.175 \\
\hline 9 & 0.162 & BDL & BDL & 0.363 & 0.226 & 0.566 & 0.167 \\
\hline 10 & 0.167 & BDL & BDL & 0.368 & 0.232 & 0.638 & 0.057 \\
\hline 11 & 0.181 & 0.023 & BDL & 0.347 & 0.230 & 0.594 & 0.198 \\
\hline 12 & 0.198 & 0.016 & $\mathrm{BDL}$ & 0.301 & 0.226 & 0.491 & 0.172 \\
\hline 13 & 0.194 & 0.082 & BDL & 0.363 & 0.236 & 0.522 & 0.041 \\
\hline 14 & 0.188 & 0.097 & BDL & 0.323 & 0.232 & 0.346 & 0.136 \\
\hline Range & 0.13-0.209 & BDL-0.097 & BDL & 0.301-1.549 & $0.197-0.236$ & $0.239-0.818$ & $0.041-0.276$ \\
\hline Mean & 0.172 & 0.054 & BDL & 0.671 & 0.219 & 0.551 & 0.166 \\
\hline
\end{tabular}

BDL refers to Below Detectable Limit of the instrument AA7000 $\left(0.01 \mu \mathrm{g} \mathrm{mL}^{-1}\right)$

The water samples collected from different sites of the Buriganga river contained 0.197 to $0.236 \mu \mathrm{g} \mathrm{mL}{ }^{-1} \mathrm{Cu}$ (Table 3). Among the total 14 water samples, only one sample was found within the recommended limit for irrigation $\left(0.20 \mu \mathrm{g} \mathrm{mL}^{-1}\right)$ as described by Ayers and Westcot (1985). Similarly, the National Academy of Science has recommended that for continuous use irrigation effluent water should not contain more than $0.20 \mu \mathrm{g} \mathrm{mL}^{-1} \mathrm{Cu}$ (Gibeault and Cockerham, 1985). The standard limit of $\mathrm{Cu}$ for domestic water supplies is 1.0 $\mu \mathrm{g} \mathrm{mL}^{-1}$ as described by USPH (De, 2002). According to ADB (1994) the standard limit of $\mathrm{Cu}$ for drinking water is $1.0 \mu \mathrm{g} \mathrm{mL}^{-1}$ and livestock drinking water is $5.00 \mu \mathrm{g} \mathrm{mL}{ }^{-1}$. Considering these limits, $\mathrm{Cu}$ concentrations in all water samples were found within the suitable range (Table 3 ). A similar observation was reported by Meghla et al. (2013), for the waters collected from the Turag river in Dhaka city, Bangladesh. The water samples collected from different sites of Buriganga river contained different amount of $\mathrm{Zn}$ and the amount varied from 0.239 to $0.818 \mu \mathrm{g} \mathrm{mL}^{-1}$ with a mean value of $0.551 \mu \mathrm{g} \mathrm{mL}^{-1}$ (Table 3 ). According to Ayers and Westcot (1985), the maximum permissible limit of $\mathrm{Zn}$ in irrigation water is $2.00 \mu \mathrm{g}$ $\mathrm{mL}^{-1}$. Considering this limit as standard, all samples were found suitable for irrigation. The standard of $\mathrm{Zn}$ for domestic water supplies is $5.5 \mu \mathrm{g} \mathrm{mL}^{-1}$ as described by USPH (De, 2005). The standard of $\mathrm{Zn}$ for drinking water is $5.0 \mu \mathrm{g} \mathrm{mL}^{-1}$ (ADB, 1994). Considering these limits, $\mathrm{Zn}$ concentrations in all samples were within the suitable range for all purposes (Table 4). Similar observation was reported by Rahman et al. (2012) and Bakali et al. (2014), for the seasonal variations in the Turag river and Tongi area water quality, respectively. The concentration of $\mathrm{Mn}$ in water samples collected from Buriganga river ranged from 0.041 to $0.276 \mu \mathrm{g}$ $\mathrm{mL}^{-1}$ with a mean value of $0.166 \mu \mathrm{g} \mathrm{mL}^{-1}$ (Table 3). According to Ayers and Westcot (1985), the highest recommended concentration of $\mathrm{Mn}$ for irrigation water is $0.20 \mu \mathrm{g} \mathrm{mL} \mathrm{mL}^{-1}$. Considering this limit, $\mathrm{Mn}$ concentration in $21.43 \%$ samples (03 water samples out of 14 samples) exceeded the maximum acceptable level indicating Mn toxicity in water of the study area and for this reason those samples are not permissible for long term irrigation. On the other hand, according to WHO (2008), the guideline value of Mn for drinking water is $0.40 \mu \mathrm{g} \mathrm{mL}^{-1}$. It is evident from the results mentioned above that all the water samples were suitable for drinking purpose as regards to Mn content in waters. The standard of Mn for domestic water supplies is $<0.05 \mathrm{mg} \mathrm{L}^{-1}$ as reported by USPH (De, 2002). Therefore, $92.86 \%$ samples for the study area were 
found unsuitable for domestic water supplies in respect

of Mn content.

Table 4. Comparison of heavy metal concentration $\left(\mu \mathrm{g} \mathrm{ml}^{-1}\right)$ in the water samples of the Buriganga with different standard values and with the previous report on the Buriganga

\begin{tabular}{|c|c|c|c|c|c|c|c|}
\hline \multirow{2}{*}{$\begin{array}{l}\text { Trace } \\
\text { metal }\end{array}$} & \multirow{2}{*}{$\begin{array}{c}\text { This study } \\
\text { average }\left(\mu \mathrm{g} \mathrm{mL} L^{-1}\right)\end{array}$} & \multicolumn{4}{|c|}{ Standard values $\left(\mu \mathrm{g} \mathrm{mL}^{-1}\right)$} & \multicolumn{2}{|c|}{ Report on Buriganga $^{\mathrm{e}}$} \\
\hline & & DWS as MCL ${ }^{a}$ & $\mathrm{DWGV}^{\mathrm{b}}$ & $\mathrm{TRV}^{\mathrm{c}}$ & DWSB $^{\mathrm{d}}$ & Summer & Winter \\
\hline $\mathrm{pH}$ & 3.38 & $6.5-8.5$ & $6.5-9.5$ & - & $6.5-8.5$ & - & - \\
\hline $\mathrm{EC}$ & 5264.35 & - & - & - & 2250 & - & - \\
\hline $\mathrm{Ca}$ & 0.78 & - & - & - & 75 & - & - \\
\hline $\mathrm{Mg}$ & 0.89 & - & - & - & 35 & - & - \\
\hline $\mathrm{K}$ & 27 & - & - & - & 12 & - & - \\
\hline $\mathrm{Na}$ & 140.4 & - & - & - & 200 & - & - \\
\hline $\mathrm{Cr}$ & 0.17 & 0.1 & 0.05 & 0.011 & 0.05 & 1.43 & 1.96 \\
\hline $\mathrm{Pb}$ & 0.05 & 0.015 & 0.01 & 0.0025 & 0.05 & 0.50 & 0.23 \\
\hline $\mathrm{Cd}$ & BDL & 0.005 & 0.003 & 0.0022 & 0.005 & 0.16 & 0.22 \\
\hline $\mathrm{Fe}$ & 0.67 & 0.3 & - & - & $0.3-1$ & - & - \\
\hline $\mathrm{Cu}$ & 0.22 & 1.3 & 2.0 & 0.009 & 1.0 & 1.71 & 2.74 \\
\hline $\mathrm{Zn}$ & 0.09 & 5 & - & 0.118 & 5.0 & 0.26 & 0.22 \\
\hline $\mathrm{Mn}$ & 0.17 & 0.05 & 0.4 & - & 0.1 & - & - \\
\hline
\end{tabular}

a drinking water standard (DWS) as maximum contaminant level (MCL) proposed by US EPA

${ }^{\mathrm{b}}$ drinking water guideline values WHO (2008)

${ }^{\mathrm{c}}$ TRV for fresh water proposed by US EPA (1999)

${ }^{\mathrm{d}}$ drinking water standard for Bangladesh proposed through ECR (1997)

${ }^{\mathrm{e}}$ Mohiuddin et al., (2011)

Heavy metal concentration in the water samples of different sites of the Buriganga is compared with different standard values and with the previous report on the Buriganga and presented in Table 4. The average concentration of $\mathrm{Cr}, \mathrm{Pb}$ and $\mathrm{Cu}$ the Buriganga is about 10 times lower than the samples of same river presented by Mohiuddin et al., 2011. The average concentration $\mathrm{Zn}$ is also much lower than the previous report and $\mathrm{Cd}$ content this time is below the detectable range of the instrument $\left(<0.01 \mu \mathrm{g} \mathrm{mL}^{-1}\right)$.

\section{References}

ADB (Asian Development Bank). 1994. Training Manual for Environmental Monitoring. USA: Engineering Science Inc., pp. 2-16.

Agarwal, R.R.; Yadav, J.P. and Gupta, R.N. 1982. Saline and Alkali Soils of India. Indian Council of Agricultural Research, New Delhi, India. pp. 223228.

Ahmad, M. K.; Islam, S.; Rahman S.; Haque. M. R. and Islam, M. M. 2010. Heavy Metals in Water, Sediment and Some Fishes of Buriganga River, Bangladesh. International Journal of Environmental Research, 4: 321-332.

Alam, A. M. S.; Islam, M. A.; Rahman, M. A.; Siddique, M. N. and Matin, M. A. 2003. Comparative study of the toxic metals and nonmetal status in the major river system of Bangladesh. Dhaka University Journal of Science, 51: 201-208.

\section{Conclusions}

The $\mathrm{pH}$ of water ranged from 4.09 to 7.41 and EC was 346 to $7720 \mu \mathrm{S} \mathrm{cm}^{-1}$. The mean concentration of $\mathrm{Ca}$, $\mathrm{Mg}, \mathrm{Na}, \mathrm{K}$ in water samples were $0.779,0.889,140.39$, $26.9 \mu \mathrm{g} \mathrm{mL}^{-1}$, respectively. The mean concentration of $\mathrm{Cr}, \mathrm{Pb}, \mathrm{Fe}, \mathrm{Cu}, \mathrm{Zn}$ and $\mathrm{Mn}$ in water samples were 0.17 , $0.05,0.67,0.22,0.55$ and $0.17 \mu \mathrm{g} \mathrm{mL}^{-1}$, respectively; while the amount of $\mathrm{Cd}$ in all samples and $\mathrm{Pb}$ in 10 samples was below detectable limit of the instrument. Chromium content in Buriganga river water sample was thirteen to twenty times higher than that of toxicity reference value (TRV) for fresh water proposed by US EPA.

Alam, K. 2008. Cost-Benefit Analysis of Restoring Buriganga River, Bangladesh. Water Resources Development, 24: 593-607.

Ali, M. Y.; Amin, M. N. and Alam, K. 2008. Ecological Health Risk of Buriganga River, Dhaka, Bangladesh. Hydro Nepal: Journal of Water, Energy and Environment, 3: 1-4.

APHA (American Public Health Association) 2005: Standard Methods for the Examination of Water and Wastewater. 21st Edition. AWWA and WEF, Washington, USA. pp. 1-175.

Ayers, R. S. and Westcot, D. W. 1985. Water Quality for Agriculture. FAO Irrigation and Drainage Paper, 29: 8-96.

Bakali, B.; Younus, M. M. and Zakir, H. M. 2014. Water quality evaluation of Tongi area in Bangladesh: an impact of industrialization. Journal 
of Chemical, Biological and Physical Scienc, 4: 1735-1752.

Dassenakis, M.; Scoullos, M.; Foufa, E.; Krasakopoulou, E.; Pavlidou, A. and Kloukiniotou, M. 1998. Effects of multiple source pollution on a small Mediterranean river. Applied Geochemistry, 13: $197-211$.

De, A. K. 2002. Environmental Chemistry, 4th. Ed, New Age International (P) Ltd., New Delhi. 761 pages.

DoE (Department of Environment). 2005. Government of the People's Republic of Bangladesh, Ministry of Environment and Forest, Department of Environment. Dhaka, Bangladesh.

ECR. (The Environment Conservation Rules), 1997. Department of Environment, Government of the People's Republic of Bangladesh. Poribesh Bhaban E-16, Agargaon, Shere Bangla Nagar Dhaka 1207, Bangladesh. 179-226.

Gibeault, V. A. and Cockerham, S. T. 1985. Turfgrass, Water Conservation. ANR Publications, University of California, p. 155.

Meghla, N. T.; Islam, M. S.; Ali, M. A.; Suravi. and Sultana, N. 2013. Assessment of physicochemical properties of water from the Turag River in Dhaka City, Bangladesh. International Journal of Current Microbiology and Applied Science, 2: 155-167.

Miller, C. V.; Foster, G. D. and Majedi, B. F. 2003. Baseflow and stormflow metal fluxes from two small agricultural catchments in the coastal plain of Chesapeake Bay Basin, United States. Applied Geochemistry, 18: 483-501.

Mohiuddin, K. M.; Ogawa, Y.; Zakir, H. M.; Otomo, K. and Shikazono, N. 2011. Heavy metals contamination in the water and sediments of an urban river in a developing country. International Journal of Environmental Science and Technology, 8: 723-736.
Moniruzzaman, M.; Elahi, S. F. and Jahangir, M. A. A. 2009. Study on Temporal Variation of Physicochemical Parameters of Buriganga River Water through GIS (Geographical Information System) Technology. Bangladesh Journal of Science and Industrial Research, 44: 327-334.

Page, A. L.; Miller, R. H. and Kenny, D. R. 1982. Methods of Soil Analysis. Part II. Second edition, American Society of Agronomy, Inc. Madison, Wisconsis, USA. 515 pages.

Richards, L. A. ((Editors). 1968. Diagnosis and Improvement of Saline and Alkaline Soils, Agricultural Handbook 60, USDA, Oxford and IBH Publishing Company Ltd., New Delhi, India. 159 pages.

Rahman, A. K. M. L.; Islam, M.; Hossain, M. Z. and Ahsan, M. A. 2012. Study of the seasonal variations in Turag river water quality parameters. African Journal of Pure and Applied Chemistry, 6: 144-148.

Rudnick, R. L. and Gao, S. 2003. Composition of the continental crust. Treatise Geochem, 3: 1-64.

Singh, K. P.; Parwana, H. K. 1999. Ground water pollution due to industrial wastewater in Punjab state and strategies for its control. Indian Journal Environmental Protection. 19: 241-244.

US EPA (U.S. Environmental Protection Agency). 1999. Screening level ecological risk assessment protocol for hazardous waste combustion facilities. Vol. 3, Appendix E: Toxicity reference values. EPA 530-D99-001C.

US EPA (U.S. Environmental Protection Agency). 2009. National Primary Drinking Water Regulations. EPA 816-F-09-004, Washington, D.C. 20460,

WHO (World Health Organization) 2008: Guidelines for Drinking Water Quality. Third edition. 515 pages. 